Nat. Hazards Earth Syst. Sci. Discuss., doi:10.5194/nhess-2017-150, 2017

Manuscript under review for journal Nat. Hazards Earth Syst. Sci.

Discussion started: 3 May 2017

(c) Author(s) 2017. CC-BY 3.0 License.

\title{
Coastal flooding risk associated to tropical cyclones in a changing climate. Application to Port of Spain (Trinidad and Tobago)
}

\author{
Cristina Izaguirre*, Iñigo J. Losada, Antonio Espejo, Javier Diez-Sierra, Pedro Díaz-Simal \\ Environmental Hydraulics Institute "IH Cantabria", Universidad de Cantabria, Spain
}

5 Correspondence to: Cristina Izaguirre (izaguirrec@unican.es)

\begin{abstract}
The aim of this paper is to provide a methodology to assess flooding risk associated to the combination of extreme flooding levels driven by Tropical Cyclone (TCs) and relative sea level rise (RSLR). The approach is based on the risk conceptual framework where the hazard, exposure, and vulnerability are defined and combined to address flooding socioeconomic consequences in Port of Spain for present and future climate (RCP8.5 in 2050). Hazard and flooding impact

10 are assessed using a combination of statistical methods and dynamical simulations, together with a high resolution Digital Elevation Model (DEM). Combining flooding maps, exposure databases and vulnerability damage functions we have evaluated socioeconomic consequences in terms of affected population and economic damage. Besides, we have quantified the uncertainty in the results coming from the sea level rise projections and vulnerability information. The application of the methodology indicates increasing flooding threat for the future climate that could exacerbate economic losses in case of

15 inaction. The expected annual damage (EAD) in present climate is 12.24 MUSD while in 2050 it will reach 15.22 [14.8815.67] MUSD.
\end{abstract}

\section{Introduction}

Coastal flooding in TC prone areas is a threat of paramount interest for socioeconomic systems. Many of these areas are characterized by low-lying coasts and high population density, factors of exposure and vulnerability that influence the risk of

20 flooding and hence the damage and consequences (Peduzzi et al. 2012). The effects of climate change, reflected in TCs activity but mainly on RSLR which affects extreme flooding levels (Hunter et al. 2013, Woodruff et al. 2013), will aggravate coastal flooding consequences. The aim of this paper is to present an integrative methodology to assess present and future flooding risk (and its direct associated consequences) in socioeconomic systems of TC-likely areas accounting for climate change. The approach focuses on extreme water levels associated to TCs and RSLR at local scale considering the mid-term horizon year

25 2050, providing useful information for medium-term planning, implementation and optimization of coastal risk adaptation and management. The proposed approach has been applied to the case study of Port of Spain, capital city of Trinidad and Tobago. Flood risk estimation is commonly determined by means of the product of hazard, exposure and vulnerability (e.g. Aerts et al. 2013, Lickley et al. 2014, Budiyono et al. 2015, Balaguru et al. 2016). However, different approximations are carried out depending on the availability of data, the spatial scale resolution or impact models, resulting in different levels of uncertainty. 
Nat. Hazards Earth Syst. Sci. Discuss., doi:10.5194/nhess-2017-150, 2017

Manuscript under review for journal Nat. Hazards Earth Syst. Sci.

Discussion started: 3 May 2017

(c) Author(s) 2017. CC-BY 3.0 License.

Regarding the hazard, different methods are used to model TC surges which are the extreme water levels in combination with RSLR. TC damage is very sensitive to not only TC intensity but also TC track. Therefore, a shortage of observation data is not enough to consistently define return periods of the different flood levels and there is a need to increase the number of TCs. To stochastically generate synthetic TC tracks two main approaches are found in the literature. Statistical approaches are based on Monte Carlo methods that simulate synthetic TCs using historical TC statistics (Hall et al. 2013, Nakajo et al. 2014) whereas the statistical-deterministic approach simulates TC environments statistically and generates TCs in the simulated environments deterministically (Emanuel et al. 2006, Lin et al. 2012, Aerts et al. 2013, Neumann et al. 2015). Considering climate change effects on TC in the near-term (up to 2035) there is low confidence of trends in TC frequency, due to several sources of uncertainty, including the large influence of internal variability (Villarini et al. 2011, Villarini and Vecchi 2012). In the long-

10 term Knutson et al. (2010) reported a decrease or unchanged rate in the global frequency of occurrence of TCs and an increase in the mean intensity. However, substantial increases in the frequency of the most intense cyclones are projected being likely to vary by region with low confidence in region-specific projections (Emanuel et al. 2008, Bender et al. 2010, Yamada et al. 2010, Murakami et al. 2012).

During the present and upcoming centuries the sea level rise is expected to continue, with an acceleration at the mid-21st 15 century and projections for all Representative Concentration Pathway (RCP) scenarios being larger than in the AR4 (Church et al. 2013). RSLR will vary from the global average due to regional distribution and non-climate components such as natural or anthropogenic subsidence. A first, and widely used, approach to model the influence of RSLR on extreme sea levels considers the independence (linear addition) between TC surge (obtained with hydrodynamic modelling) and RSLR (Hanson et al. 2011, Pedrozo-Acuña et al. 2015) while more sophisticated techniques consider non-linearity between RSLR and storm 20 surge (Lin et al. 2012, Smith et al. 2010).

The analysis of exposure depends on the scale of the problem and the modelling approach, and is mainly limited by the availability of topographic and socioeconomic data. The topographic data will determine the uncertainty in the flooding extent and depth, while the population and land-use datasets the accuracy in the flooding exposure (Hinkel et al. 2014). The flood extent/depth is commonly determined using the bathtub model approach (e.g. Aerts et al. 2013), although at local scale, the use of hydrodynamic models would produce more realistic values (e.g. Miller et al. 2015). While the exposure information on topography and socioeconomic assets is worldwide available at more precise or rough resolution, data on vulnerability are limited. A few studies use field data or specific stage-damage functions such as Aerts et al. (2013) and Budiyono et al. (2015) while others apply generic depth-damage functions to represent vulnerability and obtain damage and consequences (Merz et al. 2010, Mokrech et al. 2015).

30 The literature review for assessing flooding risk acknowledges the need for an integrated methodology dealing with uncertainties, lack of data and different complexity of models. We present a multistep process based on: the integration of statistical and numerical models, the capability of introducing future projections of climate drivers, vulnerability and exposure and, finally, the treatment of uncertainty provides a robust framework for decision-making in Port of Spain. 
Nat. Hazards Earth Syst. Sci. Discuss., doi:10.5194/nhess-2017-150, 2017

Manuscript under review for journal Nat. Hazards Earth Syst. Sci.

Discussion started: 3 May 2017

(c) Author(s) 2017. CC-BY 3.0 License.

The paper is organized as follows: section 2 provides a description of the study site (Port of Spain), in section 3 the methods and data used are defined, including a brief discussion about sources of uncertainty, in section 4 the results are shown and section 5 gives some conclusion and discussion about the results of the paper.

\section{Study site: Port of Spain}

5 Port of Spain, the capital of Trinidad and Tobago, is a medium sized Caribbean city located on the northwest side of Trinidad Island, facing to the Gulf of Paria. Although it is not completely located within the Atlantic hurricane belt, flooding impacts associated with TC events have been suffered over the years. The climate change hazard in terms of sea level rise and TC activity changes, together with an outdated and insufficient drainage system lead to the interest of stakeholders in obtaining threat insight for the mid-term horizon year (2050) to support medium-term planning. This study is focused on the East Side

10 of the city, in the metropolitan area between Maraval River and St. Anns River, including the Port of Spain Waterfront to the south, with a total of 1120.5 hectares (figure 1).

\section{Methods and Data}

A sketch of the methodology of risk applied for the analysis of flooding impact due to the combination of extreme levels associated to TCs and RSLR in a socioeconomic system is shown in figure 2. The definition and combination of the hazard, exposure and vulnerability, where historic and future scenarios can be considered, lead to the assessment of risk. The extreme water levels are due to the combination of different dynamics: astronomical tide (AT), which is a deterministic phenomenon forced by the gravitational attraction of the sun and moon, rainfall run off (RO), river discharge (RD), storm surge (SS) and waves (W) associated to the passage of the TC, and relative sea level rise (RSLR) due to the effect of climate change and local land movements. The RO and RD are dynamics that account for the rainfall linked to the TC and that contribute, mainly, to

20 the inland flooding. The AT, SS, W and RSLR are marine dynamics that contribute to the coastal flooding. Climate scenarios are taken into account considering RSLR projections and the mid-term horizon year 2050. The exposure is defined through the socioeconomic features: digital elevation model (DEM), population (POP) and economic assets (EA). The combination of hazard and exposure using a hydraulic model leads to the flooding impact and exposed population and assets. Finally, the vulnerability is taken into account throughout the information of damage functions (DFs), which describe the relation between

25 flood depth and potential damage. Applying the damage functions to the exposed assets, the flooding risk in terms of economic damage can be determined.

The methodology introduces a series of building blocks such as the probabilistic modelling of TC impact, exploring climate change using the RCP scenarios (Van Vuuren, 2011), hydrodynamic modelling of flooding or the probability assessment of risk in terms of damage, as well as, taking into account all possible sources of uncertainty. 
Nat. Hazards Earth Syst. Sci. Discuss., doi:10.5194/nhess-2017-150, 2017

Manuscript under review for journal Nat. Hazards Earth Syst. Sci.

Discussion started: 3 May 2017

(c) Author(s) 2017. CC-BY 3.0 License.

\subsection{Hazard modelling}

Land falling TCs generate a flooding impact that is associated to several dynamics: the tidal range and storm timing to the tidal phase, the increase in water level owing to the presence and local behavior of shoaling and breaking waves, and rainfall-driven runoff. Besides, the effects of climate change on TCs intensity and frequency and, especially, RSLR will increase future extreme flood elevations (Woodruff et al. 2013). In this study coastal and inland flooding are considered including each component in the hazard analysis. The coastal flooding penetrating during the passage of a TC is characterized by the total water level (TWL) that integrates the coastal dynamics as $\mathrm{TWL}=0.043 \sqrt{\mathrm{Hs}} \cdot \mathrm{L} 0+\mathrm{SS}+\mathrm{AT}$, where $0.043 \sqrt{\mathrm{Hs}} \cdot \mathrm{L} 0$ is an empirical estimate of wave run-up/set up on dissipative beaches (Stockdon et al., 2006, being Hs the significant wave height and L0 the wave length in deep water) and SS is the storm surge, both dynamics, wind set-up generated by the wind and inverse barometer

10 effect due to sea level pressure (SLP) associated to the TC; and AT corresponds to the astronomical tide, which is reproduced using the harmonic components extracted from the tidal series of the tidal gauge of Port of Spain (GLOSS network).

Regarding climate change we consider the Representative Concentration Pathways (Moss et al. 2010) selecting the RCP8.5, which corresponds to the pathway with the highest greenhouse gas emission resulting from the exclusion of any specific climate mitigation target (Riahi et al. 2011). Foreseeably it may be the one with more visible changes in the near-term and could provide the worst case scenario in terms of climatic hazard.

\subsubsection{Tropical cyclone dynamics}

Between 1851 and 2014, 87 TCs crossed Trinidad and Tobago. According to the Saffir-Simpson scale, from the 87 events, 5 tropical storms and 3 hurricanes made landfall in the islands, being Flora (1963) and Ivan (2004) hurricanes the most catastrophic events reported with estimated losses of 30 MUSD (1963 USD) and 4.9 MUSD (2004 USD), respectively.

20 Historical observations of TCs constitute a shortage database that does not provide enough information for a proper statistical characterization of TC flooding distribution. Therefore, a methodology based on synthetic TC tracks and statistical and dynamical modelling of the physical mechanisms controlling the flood levels is proposed to characterize present and future inundation. Synthetic TC tracks generation aims to increase the historical population of TCs with the same statistical behaviour than those existing in the record (Nakajo et al., 2014) considering all possible storms consistent with basin climatology. The synthetic TC population allows to improve the historical characterization, but implies a high computational cost when dynamically modelling waves and sea levels associated with the passage of each TC. In order to reduce computational demands we have selected a modest number of storms from which the waves, sea levels, rainfall and flooding are dynamically modelled. The selection is based on a set of TC parameters defined for those TC that reach a circle of influence of $3^{\circ}$-radius centred in Port of Spain. As flood levels are related to the local behaviour of the TC in the influence area, the parameters chosen are:

30 translation speed, angle of approach, minimum pressure inside the area of influence, pressure when entering the area of influences and pressure when leaving the area of influence. Using the maximum dissimilarity algorithm (Camus et al. 2011) we have selected 300 events that cover the entire storm parameter space through optimal parameter selection. From the 300- 
Nat. Hazards Earth Syst. Sci. Discuss., doi:10.5194/nhess-2017-150, 2017

Manuscript under review for journal Nat. Hazards Earth Syst. Sci.

Discussion started: 3 May 2017

(c) Author(s) 2017. CC-BY 3.0 License.

dynamical simulations one can interpolate to obtain an estimate of the waves, surge or flooding at any intermediate point by weighting with the distance of the three most similar modelled events. The wind and rainfall fields associated with the passage of TCs are modelled using state-of-the-art analytic models such as the Hydromet-Rankine Vortex model (Holland 1980) and Rainfall Climatology and Persistence (R-Clipper model, Tuleya et al. 2007). The R-Clipper model, which is appropriated to

5 model larger spatial scales without taking into account local orography, is used due to the lack of data in Port of Spain, providing a first estimation of rainfall. Waves and surges are modelled using numerical models: the wave propagation model Simulating WAves Nearshore (SWAN, Booij et al., 1999) for waves and the two-dimensional hydrodynamic model H2D (Castanedo, 2000) solving wind set-up and the inverse barometer effect.

Regarding climate change effects in TCs, for the mid-term the Intergovernmental Panel on Climate Change (IPCC) gives low 10 confidence level to the TC projections. This is because the few studies tackling the near-term projections are no conclusive, with, for example, a decrease in the frequency projected by Knutson et al. (2013) or non-significant changes obtained by Villarini and Vecchi (2012). Besides, the changes estimated for Couple Model Intercomparison Project Phase 5 (CMIP5) are smaller than the uncertainty estimated by the Global Circulation Models (GCMs), being the natural climate variability the main source of uncertainty. Because of this and the fact that the integrated methodology proposed in this study concatenates

15 different sources of uncertainty foreseeably greater than the own projected changes in TC, we have consider no changes in the TC activity for the 2050. This agrees with Bender et al. (2010) that estimates that the time scale of emergence of projected changes in TCs exceeds 60 years.

\subsubsection{Sea Level Rise}

The average value for the global mean sea level rise for 2046-2065 (relative to the period 1986-2005) under RCP8.5 is projected

20 to be $0.29 \mathrm{~m}$ with a $5-95 \%$ range of $0.22-0.38 \mathrm{~m}$ (Wong et al., 2014). However, sea level is not rising at the same rate everywhere due to different ocean and land mechanisms (Yin et al., 2009, Mitrovica et al., 2011, Farrell and Clark, 1976, Miller et al., 2013). Consequently the regional variability and local effects are to be accounted for in impact studies.

We have taken as starting point the database of mean sea level projections of Slangen et al. (2014), which takes into account effects of atmospheric loading, plus land ice, GIA and terrestrial water sources. However it only provides projections for the end of the century. Thus, following the same pattern of regional variability we have interpolated the global mean sea level rise for 2046-2065.

The complex tectonic plate boundary where Trinidad Island lies on, with three major faults extending East-West, makes especially important the vertical land movement contribution. Miller et al. (2005) determined that the rate of sea level rise in South West Trinidad is about four times than in the North West due to the subsidence of South West Trinidad into the pull-

30 apart basin of the Gulf of Paria. Using GPS observations they stated that there is less relative vertical displacement of land masses between North Trinidad and mainland South America, that North Trinidad and the region of Point Fortin in the Gulf of Paria, where the displacement is localized. The sea level rise found in the tide gauge of Port of Spain during the period 1984-1992 was $1 \mathrm{~mm} /$ year, which is closely to the sea level rise observations in the area. Therefore, since the subsidence 
Nat. Hazards Earth Syst. Sci. Discuss., doi:10.5194/nhess-2017-150, 2017

Manuscript under review for journal Nat. Hazards Earth Syst. Sci.

Discussion started: 3 May 2017

(c) Author(s) 2017. CC-BY 3.0 License.

process is localized in the South-West of the island we have not included any vertical land movement contribution and we have considered a RSLR of $0.25 \mathrm{~m}$ [0.18, 0.33] in Port of Spain in 2050. In this work we include a new additional term in the TWL in order to account for the RSLR: TWL $=0.043 \sqrt{ } \mathrm{Hs} \cdot \mathrm{L} 0+\mathrm{SS}+\mathrm{AT}+\mathrm{RSLR}$.

\subsection{Exposure and vulnerability information}

\section{$5 \quad$ 3.2.1 Physical and socioeconomic characterization}

One of the most critical dataset required to accurately characterize the flooding impact is the topographic information. In this study, we have used a high-resolution DEM covering the area of interest (108 km2), which has been produced in the context of the project "Probabilistic Hazard and Vulnerability Assessment Report based on Climate Change Projections" developed by the Inter-American Development Bank (IDB). The elevation data is referred to the datum WGS84. The horizontal resolution

10 is $4 \mathrm{~m}$ that allows the modelling of flooding impacts considering coastal defences, increasing the accuracy of the simulation and allowing a better assessment of the exposed assets.

We use demographic data from WorldPop (Geodata Institute World Population Grid, http://www.worldpop.org.uk/) spatial datasets that provides a $100 \mathrm{~m}$ grid database with historical data and projections. From the population grid in Trinidad and Tobago in 2015 we have extract the data corresponding to the area of interest, where a total population of 39639 is located.

15 The projections of population for 2020 show a decrease in the population. Taking into account this prognosis we have decided not to use projections and consider present population in 2050 as a worst case scenario.

For economic asset exposure we have focused on the built capital at a $5 \mathrm{~km}$ grid provided by the GAR 2015 UNEP Database (Global Assessment Report on Risaster Risk 2015, http://www.preventionweb.net/english/hyogo/gar/2015/en/home/data.php?iso=ESP). The total built capital of the society is

20 measured as an accumulated value for net investments done in the past (capital stock) previously disclosing, subject to annual depreciation, the land value as a non-depreciable asset.

\subsubsection{Vulnerability definition}

The expected flooding impact damage analysis is based on specific Damage Functions (DFs) built for synthetic urban areas. The estimation of the DFs representative of the flooded area of Port of Spain is as follows. First, the pure asset DF representative of each one of the typical assets is selected (residential buildings, industrial buildings green areas...). Second, we need to obtain a joint damage function that summarizes the consequences of the flooding on the set of diverse assets existing in each specific spatial unit. Due to the lack of accurate information about the urban fabric we have decided to consider DFs representative of minimum, maximum and mean damage. The use of minimum and maximum DFs implies absolute homogeneity of the spatial unit assets, considering them very invulnerable and very susceptible, respectively. However, as this theoretical approach is very unlikely under a real situation, a sensitivity analysis is carried out combining the proposed DFs. 
Nat. Hazards Earth Syst. Sci. Discuss., doi:10.5194/nhess-2017-150, 2017

Manuscript under review for journal Nat. Hazards Earth Syst. Sci.

Discussion started: 3 May 2017

(c) Author(s) 2017. CC-BY 3.0 License.

For the first step, we have used the DFs from Hazards US, HAZUS, (FEMA 2003), that introduce the proportion of damage suffered for each asset as a function of the flood level. The functions that best represent our assets typology have been selected. We compute the envelope of the selected representative curves for the existing set both with maximum and minimum damage for each depth level, and finally, a mean damage. For the second step, the spatial average DF, we have used the methodology

5 proposed by Hallegate et al. (2013) and Huizinga (2007) that essentially proposed a linear combination of asset representative DFs. For the combination weights we have introduced those proposed by the EU-RAMSES project that have been calibrated for coastal urban areas. In order to account for uncertainty in the maximum damage estimates we combine the three DFs defined (De Moel and Aerts, 2011).

\subsection{Flood impact}

\section{$10 \quad$ 3.3.1 Flood modelling and validation}

Flooding maps are obtained using the Rapid Flood Spreading Diffusion Method-wave Explicit With Acceleration term (RFSM-EDA) which is a two-dimensional hydraulic model based on the method of storage cells that responds to a diffusive approximation of the SWE (Gouldby et al. 2008). The computational grid is based on the $4 \mathrm{~m}$-resolution DEM. The model domain receives the volumes of water flooding from two independent sources during the hydraulic simulation: coastal and inland boundaries. The coastal flooding penetrating during the passage of a TC is implemented through the reconstruction of the time series of TWL in a set of points at the nearshore. The inland source of inundation comes from rainfall run-off, which is introduced in the model as an internal boundary condition, using the simulated rain fields from the R-Clipper model. We have decided to model the river discharges of St Ann's and Maraval rivers including their basins in the computational grid instead of providing the river flow as a boundary condition. A vertical datum correction is applied in order to set the marine

20 dynamics and topographic information in the same reference level. The offset between local mean sea level and WGS84 geoid is up to $35 \mathrm{~cm}$ in Port of Spain, due to the dynamic sea surface of the ocean (Schaeffer et al., 2012). To convert the vertical datum of marine dynamics from mean sea level to the WGS84 geoid we use the absolute dynamic topography, which is the sum of the sea level anomaly and the mean dynamic topography (being the dynamic topography the difference between the mean sea surface and the geoid).

25 Different tests of flooding have been taken into account in order to calibrate the parameters of the model and validate the results. The historical hurricane Flora in 1963 and tropical storms from November 2008, August 2009, March 2012 and August 2012 have been used to conduct the tests including the simulation of flooding due to rainfall, due to coastal dynamics and due to the combined effect of both dynamics. The run-off coefficient (0.68), and Manning coefficient (0.15) (Mattocks and Forbes, 2008) have been calibrated from these tests and the validation of the flooding extent was made comparing the results with

30 graphic documents of historical floods for all events except Flora. The tests computed for different dynamics show that the flooding impact in Port of Spain is mainly due to rainfall hazard associated to TCs. As an example, Figure 3 shows the maximum flooding depth during hurricane Flora. The flooding extent has an accurate definition, matching the riverbeds and 
Nat. Hazards Earth Syst. Sci. Discuss., doi:10.5194/nhess-2017-150, 2017

Manuscript under review for journal Nat. Hazards Earth Syst. Sci.

Discussion started: 3 May 2017

(c) Author(s) 2017. CC-BY 3.0 License.

some roads such as Wrightson Rd or the South Quay, where the main problems were detected. The colour bar has been limited to $2 \mathrm{~m}$ in order to better identify the flooding depth in the areas of interest: downtown and waterfront. Higher values of flooding are obtained in the river channels (in purple).

\subsubsection{Historical and future characterization of flooding levels}

5 The statistical characterization of flooding is computed from the simulation of the 300 representative TCs selected and the reconstruction of flooding for the synthetic and historic population.

For the historical period, we have simulated the flooding for each selected TC using RFSM-EDA and obtained 300 different maps of maximum flooding depth. In each inundated cell of the DEM we have reconstructed the synthetic + historic events of flooding by weighting with the distance the most similar modelled events. Using this set of flooding events we can perform

10 the extreme analysis obtaining flooding levels, maps and inundation regime in the area for different exceedance probabilities. For the horizon year 2050, we have simulated the flooding for the 300 events considering the RSLR and its 5-95\% range introduced in the TWL boundary conditions. Thus, a total of 900 events have been simulated for the climate change scenario. Combining this dynamical information and the stochastic population of TCs we obtain a probabilistic assessment of flooding levels in future scenarios.

\section{3.4 Exposure to coastal flooding and damage evaluation}

In this study, we consider the exposure to coastal flooding as the measure of the population and the assets that would be affected by a flood in absence of flood protection (Hallegate et al. 2011). It has been calculated based on the area of land inundated (for the historical conditions and for the RSLR in 2050) and on the population and asset distribution. In order to give representative numbers of exposure to coastal flooding in the city of Port of Spain we have aggregated the spatial results into total affected population and total assets exposed. Following the same process described in section 3.1.1 we compute a probabilistic assessment obtaining the exposed population and assets associated by interpolating from the 300 simulations in present and future climate.

The economic damage associated to coastal flooding is estimated using the DFs described in section 3.2.2. In each cell of the different flooding maps (in the historic and future scenarios), the flooding depth and the DFs are taken into account to estimate the effective damage over the assets exposed. After that, the economic damage associated to a particular event is obtained aggregating the cell damages to the area of analysis. Working with these effective damages we follow the same reconstruction process and the probabilistic assessment described previously to estimate future economic damage and obtain damageprobability of occurrence curves (using the transformation $\mathrm{R}=(1 / \mathrm{v}) \cdot[1 /(1-\mathrm{p})]$, where $\mathrm{R}$ is the return period, $\mathrm{v}$ is the frequency of inundation due to TC events and $\mathrm{p}$ is the probability of occurrence, we can obtained curves of damage-return period). From

30 the historical damage curves we obtain the Expected Annual Damage (EAD), which often refers to as "risk" and obtained by calculating the area under the damage-probability of occurrence curves. 
Nat. Hazards Earth Syst. Sci. Discuss., doi:10.5194/nhess-2017-150, 2017

Manuscript under review for journal Nat. Hazards Earth Syst. Sci.

Discussion started: 3 May 2017

(c) Author(s) 2017. CC-BY 3.0 License.

In order to tackle with uncertainty coming from vulnerability a sensitivity analysis is carried out combining the mean with the minimum DFs and the mean with the maximum DFs. The linear combination proposed is $\alpha \cdot D F m i n / m a x+(1-\alpha) \cdot D F m e a n . . ~ A s$ a result we test the evolution of the damage when vulnerability is reduce or increase.

\subsection{Sources of uncertainty}

5 The assessment of risk in a climate change context implies a special focus on uncertainties associated. Decision-makers require future information about risk including uncertainties involved (Hallegatte and Mach, 2016) which will be associated to global climate policies but also to a cascade effect in the integration of several and complex models, data and methods to estimate risk.

The uncertainty related to global climate policies is manifested through the scenarios based on RCPs. The selection of any of

10 them implies the assumption of the first degree of uncertainty. Besides, the representative pathways are used for climate modelling using GCMs, which is a second source of uncertainty, underlying Earth-system processes (such as climate mechanisms that we do and do not understand) or the inherent variability of the climate system. In this work, we consider sea level rise projections for RCP8.5. The number and models considered as well as the ensemble itself introduce uncertainty in the process.

15 The different methods used (from simple to more sophisticated) to model the hazard and impact come with an inherent uncertainty. While a statistical approach is used for modelling TC activity and future projections, a hybrid methodology is applied to model the dynamics associated and the flooding impact, with models of different degree of uncertainty and complexity (dynamic simulating for waves, storm surge and flooding, and parametric models for wind and rainfall).

Another important source of uncertainty are the data, which sometimes are scarce and/or hardly available. The different source,

20 nature, spatial resolution and temporal spanning may condition the results of the risk assessment. In this work, we could make an accurate modelling of the flooding impact thanks to the use of a hydraulic model and high-resolution topographic data. However, the lack of high-resolution data for population, assets or damage functions and, therefore, the use of global data bases may introduce another set of uncertainty at this step of the process. Finally, extreme events and resulting damages lie in the tails of probability distributions that are inherently difficult to quantify or even characterize qualitatively (Hallegatte and

25 Mach, 2016).

\section{Results}

\subsection{Flooding maps}

Figure 4 shows the differences in flooding extent in Port of Spain for a $1 / 100$ flooding event (exceedance probability $\mathrm{p}=0.01$ ) in the present climate (in blue) and in year 2050 under scenario RCP8.5 for a RSLR of $25 \mathrm{~cm}$ (in red). A problem of flooding 30 can already be identified under present climate conditions, mainly due to rainfall dynamics and an out-of-date drainage system. Wrightson Rd and the area of South Quay, Independence Square and Beetham Hwy are the most problematic areas reaching 
Nat. Hazards Earth Syst. Sci. Discuss., doi:10.5194/nhess-2017-150, 2017

Manuscript under review for journal Nat. Hazards Earth Syst. Sci.

Discussion started: 3 May 2017

(c) Author(s) 2017. CC-BY 3.0 License.

maximum flooding depths of $1.8 \mathrm{~m}$ in present climate. The total area flooded is 236.6 hectares, which represents $21.12 \%$ of the total area selected.

The effect of RSLR in 2050 is reflected in the inundation of new areas at the coastline, especially in low-lying areas of the waterfront reclaimed to the sea, South Quay and Independence Square, where the flooding extent is considerably larger, with depths reaching $2.1 \mathrm{~m}$. In the low area of Maraval River the flooding extent is larger, covering almost the whole area south of South Quay. The total extension of flooding is 275.47 hectares, representing $24.6 \%$ of the total area of study.

Figure 5 displays the annual exceedance probability of the flood extent in Port of Spain. Blue dots show the curve for the historical period while black dots shows the flooding area in 2050 for a RSLR of $25 \mathrm{~cm}$. The grey strip displays the uncertainty in the estimation of the flooded area considering the 5-95\% range of RSLR projections. For the 1/100 low-probability the

10 increase in the flooded area for 2050 is $38.87 \mathrm{Ha}$ with a range of uncertainty that varies between $35.66 \mathrm{Ha}$ and 57.91 Ha. RSLR introduce changes in the frequency of inundation, which alters the return period corresponding to a low-probability event. As an example, the $1 / 100$ probability event correspond to a 210 -year return period in the present climate being reduce to a $146-$ year return period in 2050 .

\subsection{Affected population}

15 The population affected under present climate conditions is 8953 in the downtown area for the 1/100 flooding event, which represents $22.59 \%$ of the total population in the East Side. According to the population grid and the flooding map the most affected area in terms of population is Wrightson Rd and its surroundings. In the mid-term, considering no changes in the socio-economic scenario, which means constant population and the same spatial distribution, the population affected in the East Side area in 2050 under climate scenario RCP8.5 is 10142 [9922-10363] (an increase on $3 \%$ of affected population) for the same probability event.

\subsection{Assets exposed}

Exposure of capital stock provides an upper bound of damage (total loss of the assets). The total value of capital stock in the area of study is 1495 MUSD (millions of 2015 United States Dollars). Under present climate, for the 100-year return period, assets exposed are estimated in 311.22 MUSD (20.82\% of present total assets) whereas, under the RCP8.5 scenario, by 2050

25 the increase in assets exposed with respect to present climate is $3.9 \%$, up to 369.48 MUSD affected (with a 5-95\% range of 364.64-380.57 MUSD).

\subsection{Economic damage}

In Figure 6, left panel, we present the mean economic damage (black line) due to flooding for different return periods and a set of curves obtained as a linear combination of mean and minimum damage (dark to blue lines) and mean and maximum

30 damage (dark to red lines). One can see that the increase or decrease in the vulnerability level of the assets does not lead to symmetric results. Considering the 200-year flooding event, an increase of $50 \%$ in the most vulnerable assets yields to an 
Nat. Hazards Earth Syst. Sci. Discuss., doi:10.5194/nhess-2017-150, 2017

Manuscript under review for journal Nat. Hazards Earth Syst. Sci.

Discussion started: 3 May 2017

(c) Author(s) 2017. CC-BY 3.0 License.

increase of damage of $68.75 \%$ (from 32 MUSD to 54 MUSD) while a reduction in $50 \%$ of the vulnerability leads to a $50 \%$ decrease of damage (from 32 to 16 MUSD).

On the right panel, the economic damage (using the DF selected for mean damage) for different return periods for historical (black line) and future climate (RCP8.5 in 2050, red line) is shown. The uncertainty in the results for the future climate is

5 represented by the red dash lines. The thickest lines refer to the uncertainty due to RSLR 5-95\% ranges, while the thinner lines are an evolving of the results taking into account uncertainty coming from RSLR and from vulnerability information (using the minimum and maximum DFs). The EAD is 12.24 MUSD in present climate while in 2050 it reaches 15.22 MUSD. For the 100-year return period the historical economic damage is 29 MUSD whereas in 2050 it reaches 35.48 MUSD.

\section{Conclusions and discussion}

10 A methodology for assessing flooding risk due to the combination of TC extreme water levels and RSLR is proposed and applied to Port of Spain (Trinidad and Tobago). The methodology, based on the hazard-exposure-vulnerability-consequences approach, has an integrative nature with the aim of providing useful information to the policymakers, regarding their needs and available data and resources. The application to Port of Spain arises the main strengths, related to the integration of stateof-the-art methods and models, but also the main drawbacks, related to the lack of data and introduce of uncertainties at the

15 different steps of the methodology.

We propose a hybrid methodology combining statistical and numerical simulations to characterize the flooding impact in Port of Spain (for present and future climate). The use of statistical methods such as synthetic generation of TC tracks allows to cover a wide range of possible storms and outline climate change scenarios and horizon years of analysis. Besides, the hybrid approach combining numerical simulations with statistical reconstruction is used to obtain efficiently impact exposure and

20 socioeconomic consequences. From a representative set of TCs we model the hazard (waves, surges and rainfall), impact (flooding) and risk/consequences (affected population and economic damage) accounting for uncertainty that could be bounded with high-resolution socioeconomic data and specific damage functions. Note that the inclusion of the vulnerability component converts the assets exposed to economic damage, changing the estimation of economic consequences in Port of Spain in the present climate of $91 \%$ for the 100-year flooding event (from 311.22 to 28 MUSD).

25 The application of the methodology to Port of Spain points out the rainfall as the main driver of present inland flooding and RSLR as the aggravating hazard in the coastal area in 2050. In addition to increasing the flooding extent, RSLR changes the frequency of inundation, reducing the $1 / 100$ probability event from 210-year return period in the present climate to a 146-year return period in 2050 . 
Nat. Hazards Earth Syst. Sci. Discuss., doi:10.5194/nhess-2017-150, 2017

Manuscript under review for journal Nat. Hazards Earth Syst. Sci.

Discussion started: 3 May 2017

(c) Author(s) 2017. CC-BY 3.0 License.

(c) (i)

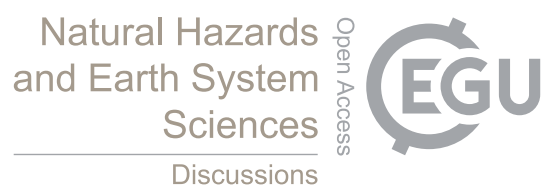

\section{References}

Aerts J.C.J.H., N. Lin, W.J. Wounter Botzen, K. Emanual and H. de Moel, 2013. Low-probability flood risk modelling for New York City. Risk Analysis, doi: 10.1111/risa.12008.

5 Balaguru K., D.R. Judi, and L.R. Leung, 2016. Future hurricane storm surge risk for the U.S. gulf and Florida coasts based on projections of thermodynamic potential intensity. Climatic Change, 138, 99-110.

Bárcena, J. F., García, A., Gómez, A. G., Álvarez, C., Juanes, J. A., \& Revilla, J. A., 2012. Spatial and temporal flushing time approach in estuaries influenced by river and tide. An application in Suances Estuary (Northern Spain). Estuarine, Coastal and

10 Shelf Science, 112, 40-51.

Bender M.A., T.R. Knutson, R.E. Tuleya, J.J. Sirutis, G.A. Vecchi, S.T. Garner, and I.M. Held, 2010. Modeled Impact of Anthropogenic Warming on the Frequency of Intense Atlantic Hurricanes. Science, 327, 454-458.

15 Booij, N., Ris, R.C., Holthuijsen, L.H., 1999. A third-generation wave model for coastal regions. Part I: model description and validation. Journal of Geophysical Research, 104 (C4), 7649-7666.

Budiyono Y., J. Aerts, J. Brinkman, M.A. Marfai, and P. Ward, 2015. Natural Hazards, 75, 389-413.

20 Camus P., F. J. Mendez, R. Medina, and A. S. Cofiño, 2011. Analysis of clustering and selection algorithms for the study of multivariate wave climate, Coastal Eng., 58(6), 453-462.

Camus, P., M. Menendez, F. J. Méndez, C. Izaguirre, A. Espejo, V. Cánovas, J. Perez, A. Rueda, I. J. Losada, and R. Medina, 2014. A weather-type statistical downscaling framework for ocean wave climate. Journal of Geophysical Research: Oceans,

25 119, doi:10.1002/2014JC010141.

Carton J.A., and B. S. Giese, 2008. A Reanalysis of Ocean Climate Using Simple Ocean Data Assimilation (SODA). Mon. Wea. Rev., 136, 2999-3017.

30 Castanedo, S., 2000. Desarrollo de un modelo hidrodinámico tridimensional para el estudio de la propagación de ondas largas en estuarios y zona someras. PhD Tesis, Departamento de Ciencias y Técnicas del Agua y del Medio Ambiente, Universidad de Cantabria, Santander, Spain (in Spanish). 
Nat. Hazards Earth Syst. Sci. Discuss., doi:10.5194/nhess-2017-150, 2017

Manuscript under review for journal Nat. Hazards Earth Syst. Sci.

Discussion started: 3 May 2017

(c) Author(s) 2017. CC-BY 3.0 License.

(c) (i)

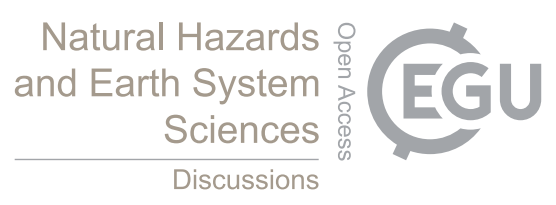

Church, J.A., P.U. Clark, A. Cazenave, J.M. Gregory, S. Jevrejeva, A. Levermann, M.A. Merrifield, G.A. Milne, R.S. Nerem,

P.D. Nunn, A.J. Payne, W.T. Pfeffer, D. Stammer and A.S. Unnikrishnan, 2013. Sea Level Change. In: Climate Change 2013:

The Physical Science Basis. Contribution of Working Group I to the Fifth Assessment Report of the Intergovernmental Panel on Climate Change [Stocker, T.F., D. Qin, G.-K. Plattner, M. Tignor, S.K. Allen, J. Boschung, A. Nauels, Y. Xia, V. Bex and

5 P.M. Midgley (eds.)]. Cambridge University Press, Cambridge, United Kingdom and New York, NY, USA.

Christensen, J.H., K. Krishna Kumar, E. Aldrian, S.-I. An, I.F.A. Cavalcanti, M. de Castro, W. Dong, P. Goswami, A. Hall, J.K. Kanyanga, A. Kitoh, J. Kossin, N.-C. Lau, J. Renwick, D.B. Stephenson, S.-P. Xie and T. Zhou, 2013. Climate Phenomena and their Relevance for Future Regional Climate Change. In: Climate Change 2013: The Physical Science Basis. Contribution 10 of Working Group I to the Fifth Assessment Report of the Intergovernmental Panel on Climate Change [Stocker, T.F., D. Qin, G.-K. Plattner, M. Tignor, S.K. Allen, J. Boschung, A. Nauels, Y. Xia, V. Bex and P.M. Midgley (eds.)]. Cambridge University Press, Cambridge, United Kingdom and New York, NY, USA, pp. 1217-1308, doi: 10.1017/CBO9781107415324.028.

De Moel H, Aerts JCJH, 2011. Effect of uncertainty in land use, damage models and inundation depth on flood damage 15 estimates. Natural Hazards, 58, 407-425.

Emanuel, K., S. Ravela, E. Vivant, and C. Risi, 2006. A statistical deterministic approach to hurricane risk assessment. Bull. Am. Meteorol. Soc., 87, 299-314.

20 Emanuel, K., Sudararajan R. and Williams J., 2008. Hurricanes and global warming: Results from downscaling IPCC AR4 simulations. Bulletin of the American Meteorology Society, 89, 347-367.

Espejo A., F.J. Méndez, R. Medina, and S. Al-Yahyai, 2015. Seasonal probabilistic forecasting of tropical cyclone activity in the North Indian Ocean. Journal of Flood Risk Management, DOI: 10.1111/jfr3.12197.

25

Farrell, W. E., and J. A. Clark, 1976: On postglacial sea level. Geophys. J. R. Astron.

Soc., 46, 647-667.

FEMA (Federal Emergency Management Agency). 2003 with updates through 2009. Guidelines and Specifications for Flood

Hazard Mapping Partners.

GAR 2015. Global Assessment Report on Disaster Risk Reduction. The United Nations Office for Disaster Risk Reduction, $266 \mathrm{pp}$. 
Nat. Hazards Earth Syst. Sci. Discuss., doi:10.5194/nhess-2017-150, 2017

Manuscript under review for journal Nat. Hazards Earth Syst. Sci.

Discussion started: 3 May 2017

(c) Author(s) 2017. CC-BY 3.0 License.

(c) (i)

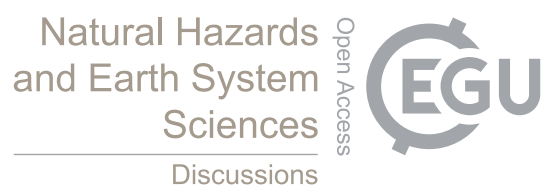

Gouldby, B., Sayers, P., Mulet-Marti, J., Hassan, M. and Benwell, D., (2008). A methodology for regional-scale flood risk assessment. Proceedings of the Institution of Civil Engineers- Water Management, 161(3), 169-182.

Hall, T.M., and A.H. Sobel, 2013. On the impact angle of hurricane Sandy's New Jersey landfall. Geophysical Research 5

Letters, 40, 2312-2315.

Hallegatte S., C. Green, R.J. Nicholls and J. Corfee-Morlot, 2013. Future flood losses in major coastal cities. Nature Climate Change, 3, 802-806.

10 Hallegate S., and K.J. Mach, 2016. Make climate-change assessments more relevant. Nature, 534, 613-615.

Hanson S., R. Nicholls, N. Ranger, S. Hallegatte, J. Corfee-Morlot, C. Herweijer, and J. Chateau, 2011. A global ranking of port cities with high exposure to climate extremes. Climatic Change, 104, 89-111.

15 Hinkel J., D. Lincke, A.T. Vafeidis, M. Perrette, R.J. Nicholls, R.S.J. Tol, B. Marzeion, X. Fettweis, C. Ionescu, and A. Levermann, 2014. Coastal flood damageand adaptation costs under 21st century sea level rise. Proceedings of the National Academy of Science, 111(9), 3292-3297.

Holland, G. J., 1980. An analytic model of the wind and pressure profiles in hurricanes.

20 Mon. Wea. Rev. 108, 1212-1218.

Huizinga, H. J., 2007. Flood damage functions for EU member states. Implemented in the frame- of the contract \#382442F1SC awarded by the European Commission - Joint Research Centre.

25 Hunter J.R., J.A. Church, N.J. White, and X. Zhang, 2013. Towards a global regionally varying allowance for sea-level rise. Ocean Engineering, 71, 17-27.

Kirtman, B., S.B. Power, J.A. Adedoyin, G.J. Boer, R. Bojariu, I. Camilloni, F.J. Doblas-Reyes, A.M. Fiore, M. Kimoto, G.A. Meehl, M. Prather, A. Sarr, C. Schär, R. Sutton, G.J. van Oldenborgh, G. Vecchi and H.J. Wang, 2013. Near-term Climate

30 Change: Projections and Predictability. In: Climate Change 2013: The Physical Science Basis. Contribution of Working Group I to the Fifth Assessment Report of the Intergovernmental Panel on Climate Change [Stocker, T.F., D. Qin, G.-K. Plattner, M. Tignor, S.K. Allen, J. Boschung, A. Nauels, Y. Xia, V. Bex and P.M. Midgley (eds.)]. Cambridge University Press, Cambridge, United Kingdom and New York, NY, USA. 
Nat. Hazards Earth Syst. Sci. Discuss., doi:10.5194/nhess-2017-150, 2017

Manuscript under review for journal Nat. Hazards Earth Syst. Sci.

Discussion started: 3 May 2017

(c) Author(s) 2017. CC-BY 3.0 License.

(c) (i)

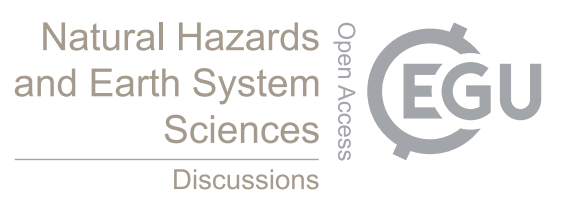

Knutson T.R., et al. 2010. Tropical cyclones and climate change. Nature Geoscience, 3, 157-163.

Knapp, K. R., M.C. Kruk, D.H. Levinson, H.J. Diamond, and C.J. Neumann, 2010. The International Best Track Archive for Climate Stewardship (IBTrACS): Unifying tropical cyclone best track data. Bull. Am. Meteorol. Soc. 91, 363-376.

Lin N., Emanuel K., Oppenheimer M., Vanmarcke E., 2012. Physically based assessment of hurricane surge threat under climate change. Nature Climate Change, 1389, doi:10.1038/NCLIMATE1389.

Lin N., and K. Emanuel, 2015. Grey swan tropical cyclones. Nature Clim. Change, doi: 10.1038/NCLIMATE2777.

10

Lickley M.J., N. Lin and H.D. Jacoby, 2014. Analysis of coastal protection under rising flood risk. Climate Risk Management, $6,18-24$.

Mattocks, and C. forbes, 2008. A real-time, event-triggered storm surge forecasting system for the state of North Carolina. 15 Ocean Modelling, 25, 3-4, 95-119.

Merz B., H. Kreibich, R. Schwarze, and A. Thieken, 2010. Assessment of economic flood damage. Nat. Hazards Earth Syst. Sci., 10, 1697-1724.

20 Miller K.M., J. Hamilton, and D. Neale, 2005. Vertical Datums in a Fault Zone: Influences of Plate Tectonics in Trinidad, West Indies. Pharaohs to Geoinformatics.

Miller, K. G., R. E. Kopp, B. P. Horton, J. V. Browning, and A. C. Kemp, 2013. A geological perspective on sea-level rise and impacts along the U.S. mid-Atlantic coast. Earth's Future, 1, 3-18.

25

Miller A., S.N. Jonkman, and M. Van Ledden, 2015. Risk to life due to flooding in post-Katrina New Orleans. Nat. Hazards Earth Syst. Sci., 15, 59-73.

Mitrovica, J. X., N. Gomez, E. Morrow, C. Hay, K. Latychev, and M. E. Tamisiea, 2011. On the robustness of predictions of 30 sea-level fingerprints. Geophys. J. Int., 187, 729-742.

Mokrech M., A.S. Kebede, R.J. Nicholls, F. Wimmer, and L. Feyen, 2015. An integrated approach for assessing flood impacts due to future and socio-economic conditions and the scope of adaptation in Europe. Climatic Change, 128, 245-260. 
Nat. Hazards Earth Syst. Sci. Discuss., doi:10.5194/nhess-2017-150, 2017

Manuscript under review for journal Nat. Hazards Earth Syst. Sci.

Discussion started: 3 May 2017

(c) Author(s) 2017. CC-BY 3.0 License.

(c) (i)

Natural Hazards

and Earth System

Sciences

Discussions

Moss R.H., J.A. Edmonds, K.A. Hibbard, M.R. Manning, S.K. Rose, D.P. van Vuuren, T.R. Carter, S. Emori, M. Kainuma, T. Kram, G.A. Meehl, J.F.B. Mitchell, N. Nakicenovic, K. Riahi, S.J. Smith, R.J. Stouffer, A.M. Thomson, J.P. Weyant, and T.J. Wilbanks, 2010. The next generation of scenarios for climate change research and assessment. Nature, 463, 747-756.

5 Murakami, H. et al., 2012. Future changes in tropical cyclone activity projected by the new high-resolution MRI-AGCM. Journal of Climate, 25, 3237-3260.

Nakajo S., N. Mori, T. Yasuda, and H. Mase, 2014. Global Stochastic Tropical Cyclone Model Based on Principal Component Analysis and Cluster Analysis. Journal of Applied Meteorology and Climatology, 53, 1547-1577.

10

Neumann J.E., K.A. Emanuel, S. Ravela, L.C. Ludwig, and A. Verly, 2015. Risks of coastal storm surge and the effect of sea level rise in the Red River Delta, Vietnam. Sustainability, 7, 6553-6572.

Pedrozo-Acuña, A., R. Damania, M.A. Laverde-Barajas, and D. Mira-Salama, 2015. Assessing the consequences of sea-level rise in the coastal zone of Quintana Roo, México: the costs of inaction. J. Coast. Conserv. 19, 227-240.

Peduzzi, P., B. Chatenoux, H. Dao, A. De Bono, C. Herold, J. Kossin, F. Mouton and O. Nordbeck, 2012. Global trends in tropical cyclones risk. Nature Climate Change, 2 (4), 289-294.

20 Riahi, K., Rao, S., Krey, V., Cho, Ch., Chirkov, V., Fischer, G., Kindermann, G., Nakicenovic, N., and, Rafaj, P., 2011. Climatic Change 109, 33. doi:10.1007/s10584-011-0149-y.

Schaeffer, P., Y. Faugére, J. F. Legeais, A. Ollivier, T. Guinle, and N. Picot, 2012. The CNES_CLS11 Global Mean Sea Surface Computed from 16 Years of Satellite Altimeter Data. Mar. Geod., 35(sup1), 3-19.

25

Slangen A.B.A., M. Carson, C.A. Katsman, R.S.W. van de Wal, A. Köhl, L.L.A. Vermeersen, and D. Stammer, 2014. Projecting twenty-first century regional sea-level changes. Climatic Change, doi: 10.1007/s10584-014-1080-9.

Smith, J.M., M.A. Cialone, T.V. Wamsley, and T.O. McAlpin, 2010. Potential impact of sea level rise on coastal surges in southeast Louisiana. Ocean Eng. 37, 37-47.

Tuleya, R. E., DeMaria, M., and Kuligowski, R. J., 2007. Evaluation of GFDL and simple statistical model rainfall forecasts for US landfalling tropical storms. Weather and forecasting, 22(1), 56-70. 
Nat. Hazards Earth Syst. Sci. Discuss., doi:10.5194/nhess-2017-150, 2017

Manuscript under review for journal Nat. Hazards Earth Syst. Sci.

Discussion started: 3 May 2017

(c) Author(s) 2017. CC-BY 3.0 License.

(c) (i)

Natural Hazards

and Earth System

Sciences

Discussions

van Vuuren, D.P., Edmonds, J., Kainuma, M. et al. 2011. The representative concentration pathways: an overview. Climatic Change, 109, 5-31.

Villarini G., G.A. Vecchi, T.R.Knutson, M.Zhao and J.A. Smith, 2011. North Atlantic tropical storm frequency response to anthropogenic forcing: Projections and sources of uncertainty. Journal of Climate, 24, 3224-3238.

Villarini G, and G.A. Vecchi, 2013. Projected increases in North Atlantic tropical cyclone intensity from CMIP5 models. Journal of Climate, 26, 3231-3240.

10 Wong, P.P., I.J. Losada, J.-P. Gattuso, J. Hinkel, A. Khattabi, K.L. McInnes, Y. Saito, and A. Sallenger, 2014. Coastal systems and low-lying areas. In: Climate Change 2014: Impacts,Adaptation, and Vulnerability. Part A: Global and Sectoral Aspects. Contribution of Working Group II to the Fifth Assessment Report of the Intergovernmental Panel on Climate Change [Field, C.B., V.R. Barros, D.J. Dokken, K.J. Mach, M.D. Mastrandrea, T.E. Bilir, M. Chatterjee, K.L. Ebi, Y.O. Estrada, R.C. Genova,

B. Girma, E.S. Kissel, A.N. Levy, S. MacCracken, P.R. Mastrandrea, and L.L.White (eds.)]. Cambridge University Press,

15 Cambridge, United

Kingdom and New York, NY, USA, pp. 361-409.

Woodruff, J.D., J.L. Irish, and S.J. Camargo, 2013. Coastal flooding by tropical cyclones and sea-level rise. Nature, 44, 504.

20 Yamada Y., K. Oouchi, M. Satoh, and H. Tomita, 2010. Projection of changes in tropical cyclone activity and cloud height due to greenhouse warming: Global cloud-system-resolving approach. Geophysical Research Letters, 37, L07709.

Yin, J. J., M. E. Schlesinger, and R. J. Stouffer, 2009. Model projections of rapid sea level rise on the northeast coast of the United States. Nature Geosci., 2, 262-266.

25

Zhao M., I.M. Held, and S-J. Lin, 2012. Some Counterintuitive Dependencies of Tropical Cyclone Frequency on Parameters in a GCM. Journal of Atmospheric Sciences, 69, 2272-2283Aman, A. A., Cman, C., and Bman, B. B.: More test articles, J. Adv. Res., 35, 13-28, doi:10.2345/67890, 2014.

\section{Databases}

30 ASTER, Advanced Spaceborne Thermal Emission and Reflection Radiometer from the Ministry of Economy, Trade, and Industry (METI) of Japan and the United States National Aeronautics and Space Administration (NASA), 
Nat. Hazards Earth Syst. Sci. Discuss., doi:10.5194/nhess-2017-150, 2017

Manuscript under review for journal Nat. Hazards Earth Syst. Sci.

Discussion started: 3 May 2017

(c) Author(s) 2017. CC-BY 3.0 License.

(c) (i)

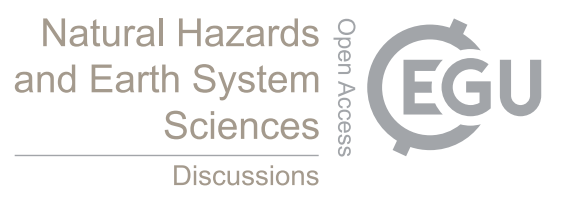

GAR 2015 UNEP Database, Global Assessment Report on Disaster Risk Reduction 2015 (http://www.preventionweb.net/english/hyogo/gar/2015/en/home/data.php?iso=ESP)

GEBCO, General Bathymetric Chart of the Ocean (GEBCO, http://www.gebco.net/)

5 Geodata Institute World Population Grid, (http://www.worldpop.org.uk/)

IBSTrACS, International Best Track Archive for Climate Stewardship (https://www.ncdc.noaa.gov/ibtracs/index.php?name=ibtracs-data-access)

10 SODA, Ocean Data Assimilation (https://climatedataguide.ucar.edu/climate-data/soda-simple-ocean-data-assimilation)

WorldPop, Geodata Institute World Population Grid (http://www.worldpop.org.uk/)

\section{Author contributions}

Cristina Izaguirre has developed the conceptual framework of the methodology, the flood modelling and the risk assessment.

15 She also prepared the manuscript and figures. Iñigo J. Losada has supervised the whole work and reviewed the manuscript. Antonio Espejo has developed the methodology for modelling tropical cyclones and reviewed the manuscript. Javier Diez modelled the tropical cyclone dynamics. Pedro Díaz-Simal has provided the economic information and tuned the damage functions for Port of Spain.

\section{Acknowledgments}

20 This paper comes out from the project "Port of Spain Probabilistic Hazard and Vulnerability Assessment based on Climate Change Projections" funded by the Inter-American Development Bank (IDB). We acknowledge the World Climate Research Programme's Working Group on Coupled Modelling, which is responsible for CMIP, and we thank the climate modelling groups for producing and making available their model output. The authors want to acknowledge Dr. Paula Camus for her fruitful comments. 
Nat. Hazards Earth Syst. Sci. Discuss., doi:10.5194/nhess-2017-150, 2017

Manuscript under review for journal Nat. Hazards Earth Syst. Sci.

Discussion started: 3 May 2017

(c) Author(s) 2017. CC-BY 3.0 License.

\section{Natural Hazards and Earth System \\ Sciences \\ Discussions}

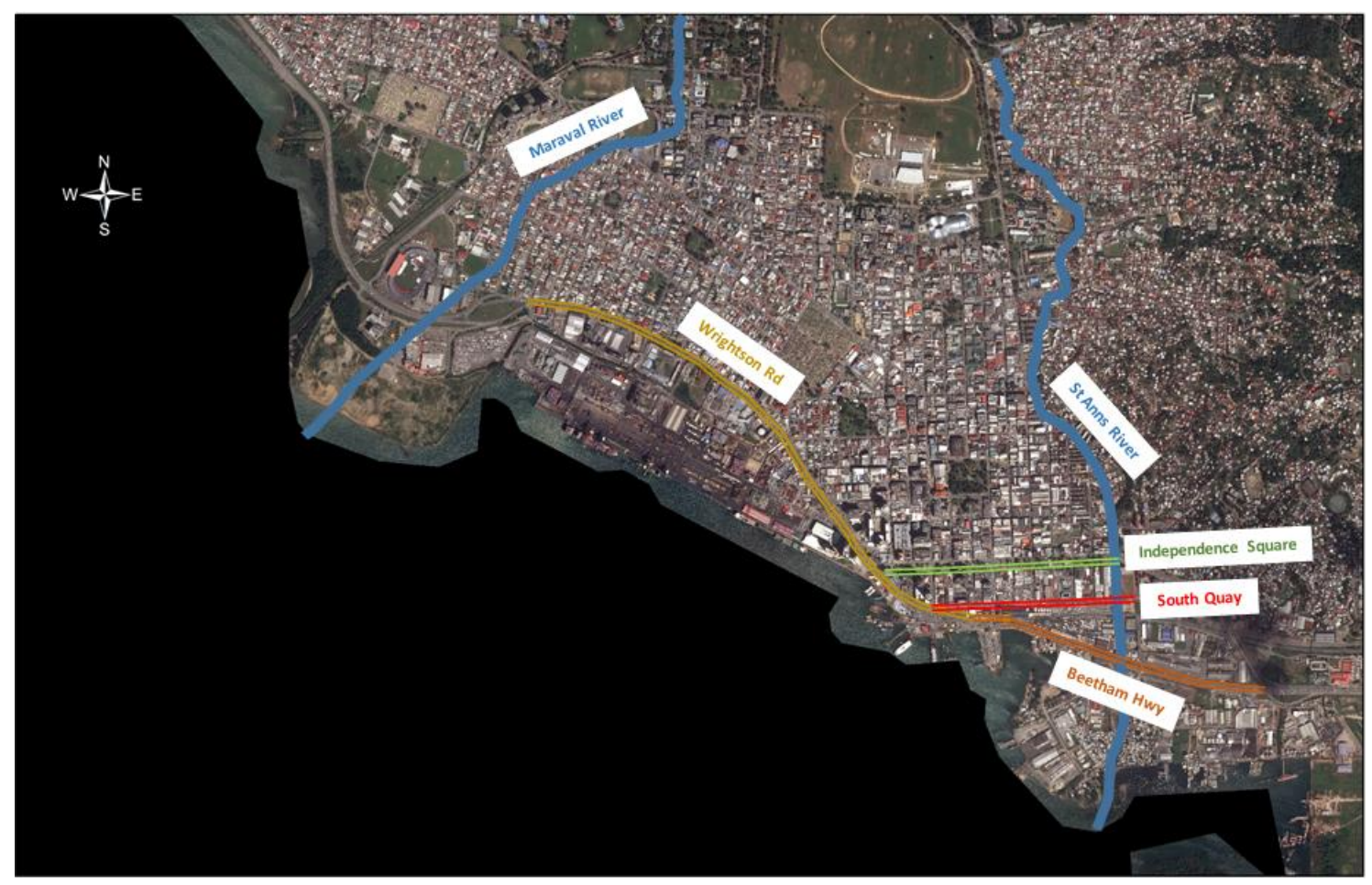

Figure 1: View of Port of Spain with the main features of the city identified. 
Nat. Hazards Earth Syst. Sci. Discuss., doi:10.5194/nhess-2017-150, 2017

Manuscript under review for journal Nat. Hazards Earth Syst. Sci.

Discussion started: 3 May 2017

(C) Author(s) 2017. CC-BY 3.0 License.

(c) (i)
Natural Hazards and Earth System

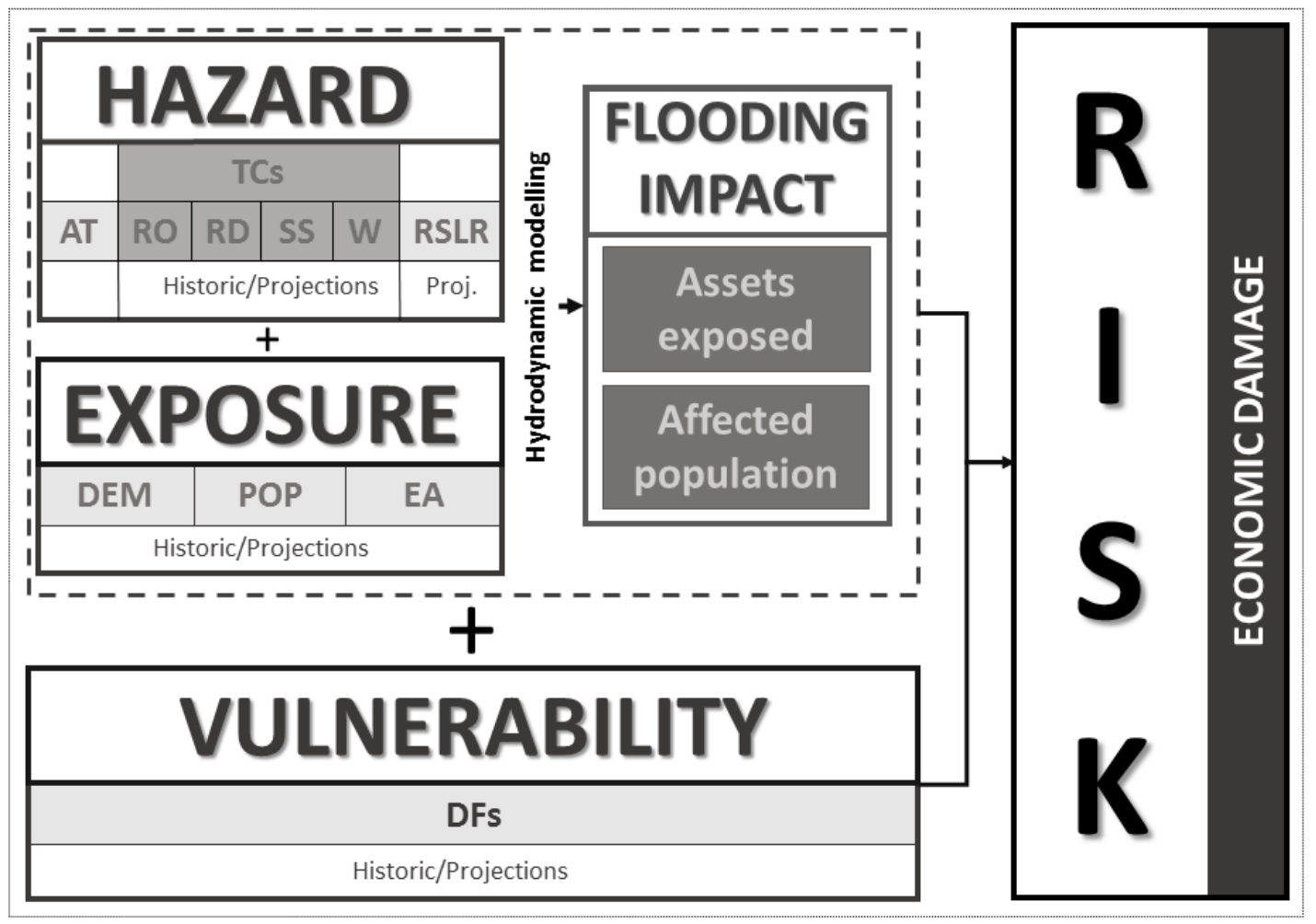

Figure 2: Sketch of the methodology of risk used for assessing flooding consequences in Port of Spain due to the combination of extreme levels associated to TCs and RSLR. 
Nat. Hazards Earth Syst. Sci. Discuss., doi:10.5194/nhess-2017-150, 2017

Manuscript under review for journal Nat. Hazards Earth Syst. Sci.

Discussion started: 3 May 2017

(c) Author(s) 2017. CC-BY 3.0 License.

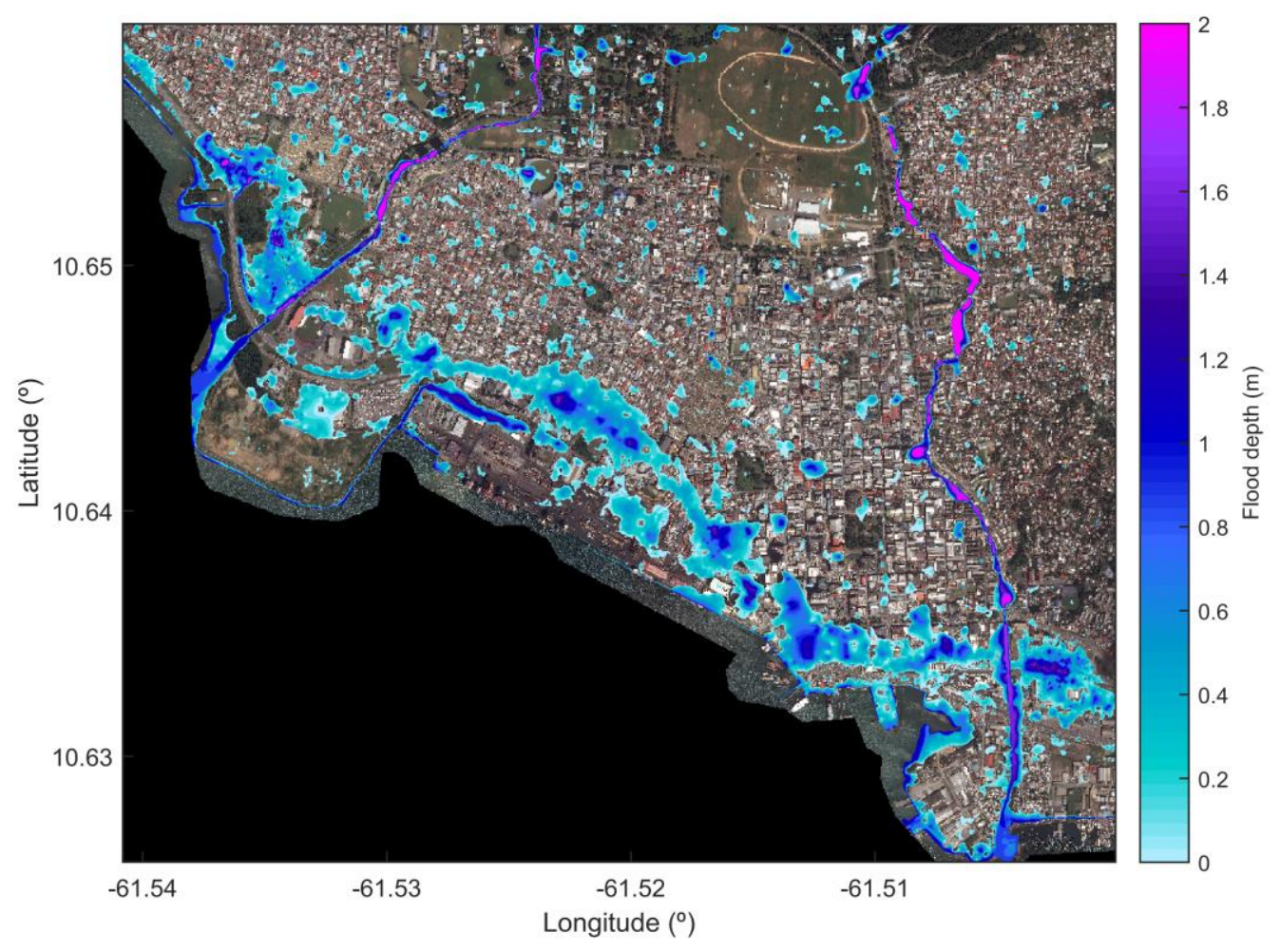

Figure 3: Inundation map of the simulation of hurricane Flora 1963. 
Nat. Hazards Earth Syst. Sci. Discuss., doi:10.5194/nhess-2017-150, 2017 Manuscript under review for journal Nat. Hazards Earth Syst. Sci.

Discussion started: 3 May 2017

(c) Author(s) 2017. CC-BY 3.0 License.

\section{Natural Hazards and Earth System Sciences \\ Discussions}

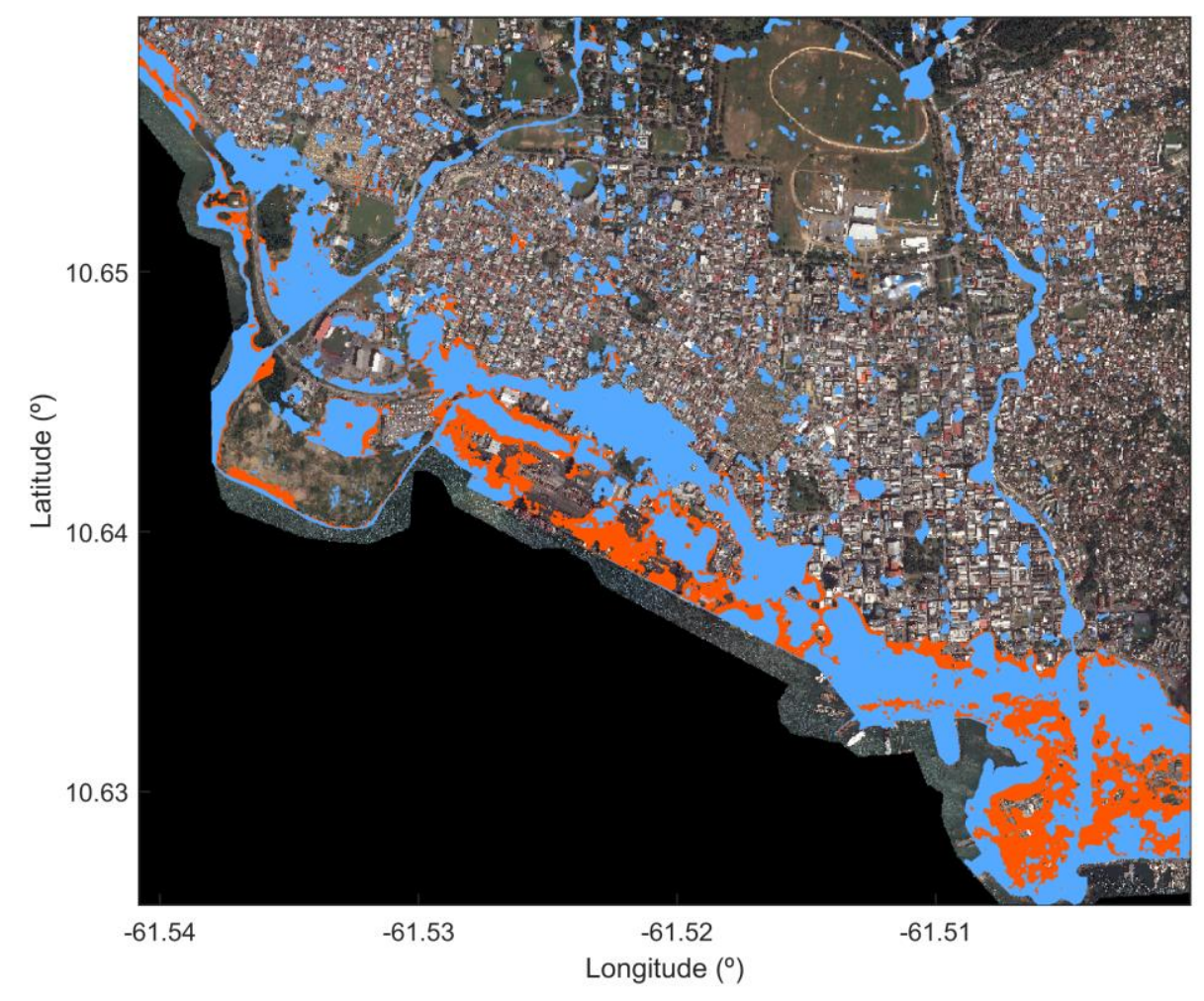

Figure 4: Comparison between the flooding extents for the 100-year return period flooding event for present climate (blue colour) and scenario RCP8.5 in 2050 (red colour). 
Nat. Hazards Earth Syst. Sci. Discuss., doi:10.5194/nhess-2017-150, 2017

Manuscript under review for journal Nat. Hazards Earth Syst. Sci.

Discussion started: 3 May 2017

(c) Author(s) 2017. CC-BY 3.0 License.

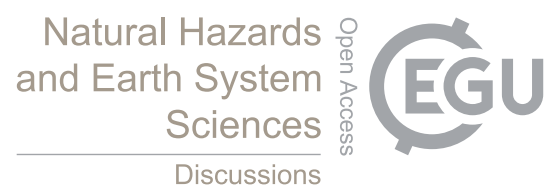

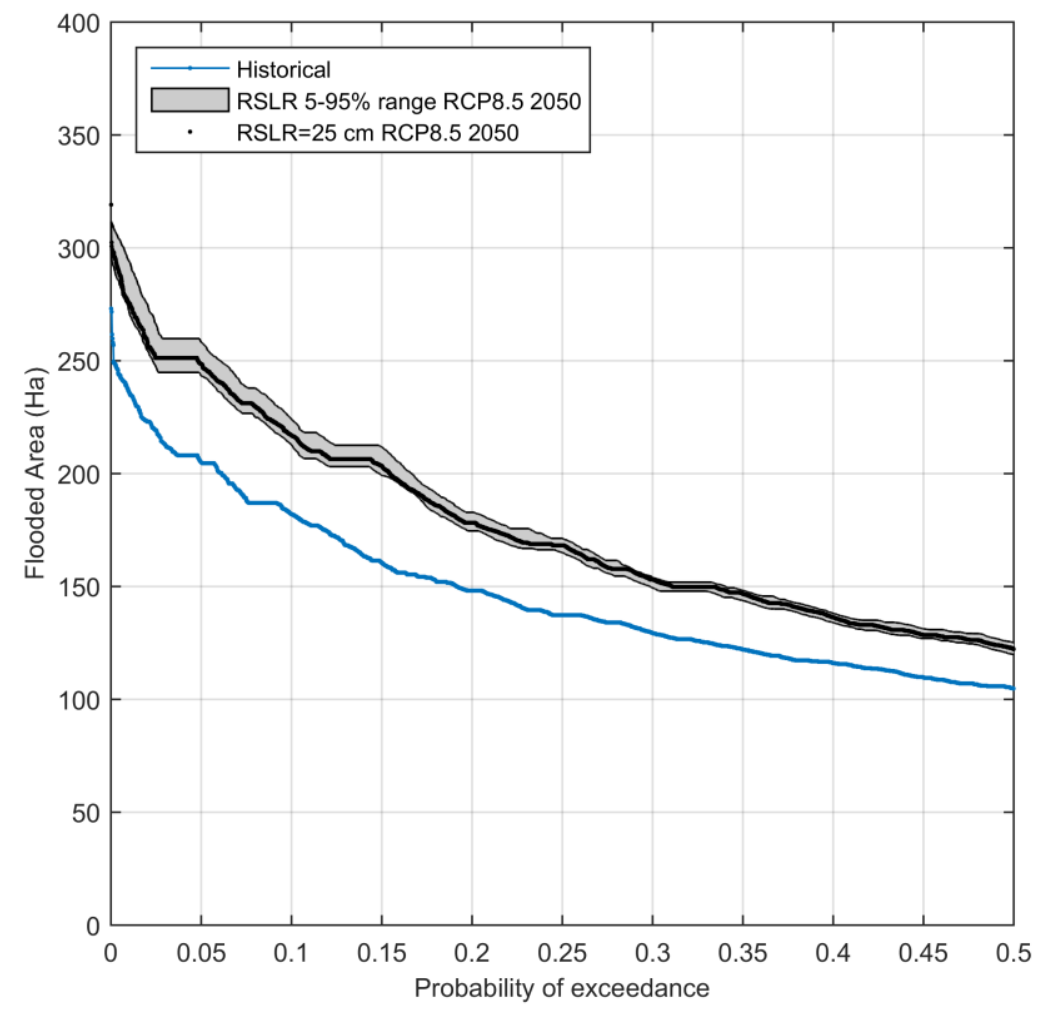

Figure 5: Curve of the annual exceedance probability-flooded area in Port of Spain for the present climate (blue dots) and year 2050 under scenario RCP8.5 (black dots for a RSLR of $25 \mathrm{~cm}$ and grey strip for the 5-95\% RSLR range). 
Nat. Hazards Earth Syst. Sci. Discuss., doi:10.5194/nhess-2017-150, 2017

Manuscript under review for journal Nat. Hazards Earth Syst. Sci.

Discussion started: 3 May 2017

(c) Author(s) 2017. CC-BY 3.0 License.

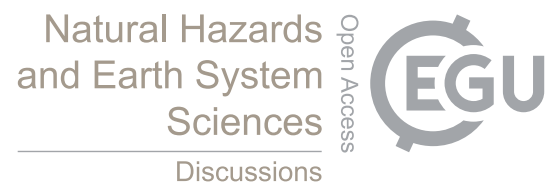

(c) (i)
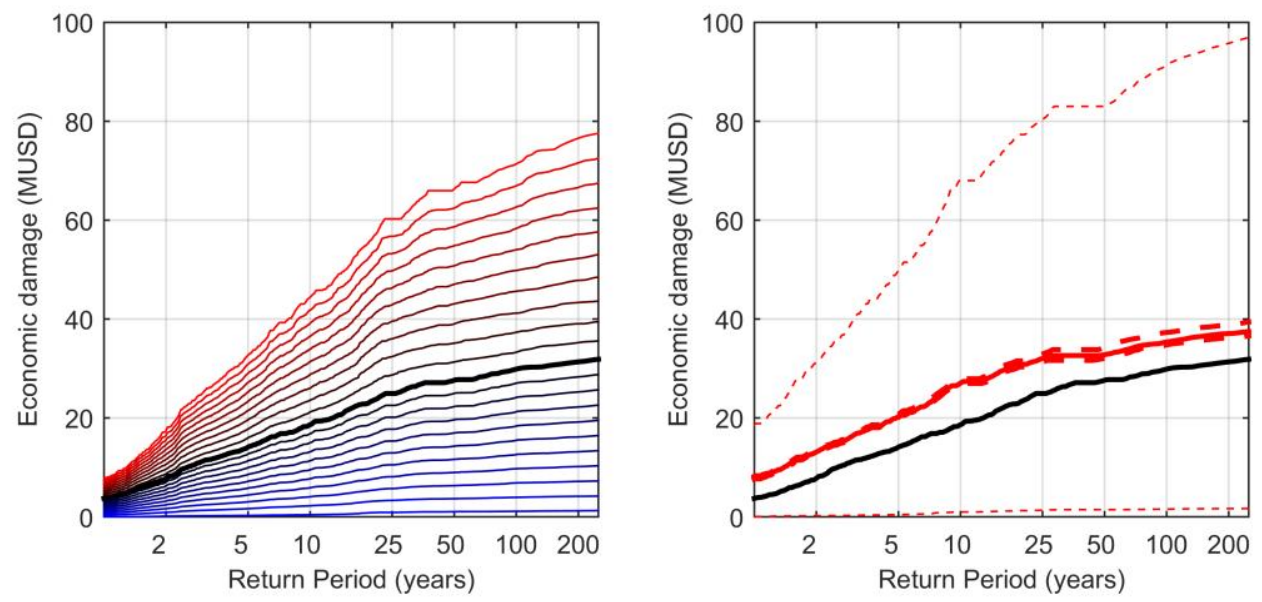

Figure 6: Sensitivity to vulnerability hypothesis and relative sea level rise uncertainty. Left panel: set of curves of economic damagereturn period for present climate: black line represents the mean damage, dark to red lines represent the linear combination of mean and maximum DFs and dark to blue lines represent the linear combination of mean and minimum DFs, each curve represent an increase of 0.1 in the $\alpha$ coefficient. Right panel: curves of economic damage-return period for present climate (black line), future climate change scenario RCP8.5 in 2050 (red solid line), uncertainty due to 5-95\% range of RSLR (dashed bold line) and uncertainty due to vulnerability information. 